University of Nebraska - Lincoln

DigitalCommons@University of Nebraska - Lincoln

Journal for the Advancement of Developing

Institute for the Advancement of Developing

Economies

Economies

2020

The Desire for Luxury in Emerging Markets: An Interactional

Perspective on Consumer Motivations in Tunisia

Pranjal Gupta,

Mouna Zaghdoudi

Follow this and additional works at: https://digitalcommons.unl.edu/jade

Part of the Econometrics Commons, Growth and Development Commons, International Economics Commons, Political Economy Commons, Public Economics Commons, and the Regional Economics

Commons

This Article is brought to you for free and open access by the Institute for the Advancement of Developing Economies at DigitalCommons@University of Nebraska - Lincoln. It has been accepted for inclusion in Journal for the Advancement of Developing Economies by an authorized administrator of DigitalCommons@University of Nebraska - Lincoln. 


\title{
The Desire for Luxury in Emerging Markets: An Interactional Perspective on Consumer Motivations in Tunisia
}

\author{
Pranjal Gupta ${ }^{1 *}$, Mouna Zaghdoudi ${ }^{2}$ \\ ${ }^{1}$ Department of Marketing, Sykes College of Business, University of Tampa, USA \\ ${ }^{2}$ Finance Department, CMAC Partners, Orlando, USA
}

\begin{abstract}
The motivations underlying the desire for luxury products and services have long been the subject of academic inquiry. An understanding of these motivations is useful for the luxury market industry to help managers formulate better marketing strategies. Further, such knowledge would also be useful to public policy makers to help them mitigate societal problems that may occur as a result of such consumption. Of particular interest is the growth of the luxury market in emerging economies. This study spotlights the luxury market in Tunisia. Previous work has demonstrated that age has a significant impact both on willingness to buy luxury products and spend significant proportions of one's disposal income on such products. As an extension, the objective of this research is to extend these findings by exploring the interactions of age with other demographic variables. Based on survey data obtained from Tunisian Facebook users and analyzed using cross tabulations, this empirical research supports the hypotheses that gender, income, education and marital status moderate the inverse relationship between age and luxury consumption.
\end{abstract}

Keywords: Demographic variables, emerging markets, interactional hypotheses, Africa, luxury consumption.

*Corresponding author: pgupta@ut.edu

\section{INTRODUCTION}

The geographic proximity of Tunisia to western Europe allows for considerable interaction between the two areas. This has been one of the factors that has made Tunisia particularly exposed to the habits, preferences and desires of western European consumers. Since most consumption of luxury products is conspicuous, fashion and luxury consumption in Europe, in particular, has a significant impact on the desire for such products and services amongst the population in Tunisia. Further, the uprisings started in 2010 that constituted the Arab Spring have had a role to play in further opening of markets and expansion of information and media access. It is reasonable to expect that an opening economy and the increasing interaction with media will further fuel the desire for luxury products as well.

Although several studies (Al-Momani, 2011; Bishku, 2013; Dadush \& Dunne, 2011; Dziri, 2013; Maddy-Weitzman, 2011; Martin, 2012; Sanchez, 2009) have been conducted to assess the postrevolution economic and political health of Tunisia and to evaluate new investment opportunities, not enough work has focused on the penetration of luxury and the interest in luxury in emerging market such as Tunisia. There is, however, some preliminary evidence that reveals a noteworthy penetration of luxury products in the Tunisian market (Gupta \& Zaghdoudi, 2016). In particular, 
Gupta and Zaghdoudi empirically studied key antecedents of luxury desire and expenditure. They show that the desire for luxury products and the expenditure on luxury products is stronger for younger consumers and less educated consumers. The theoretical rationale is that younger people or less educated consumers tend to be more reckless with their money and are more impacted by external influences. However, their empirical work, although insightful, does not delve deeper into these key relationships. Richer work exploring key moderator variables to the inverse relationship between age and the desire for and penetration of luxury products is lacking. Specifically, this study explores and tests theory pertaining to the moderating effects of a variety of demographic variables on inverse relationship between age and the desire for and expenditure on luxury products.

\section{LITERATURE REVIEW}

In the following sections, we will first briefly trace the economic, social and political conditions of Tunisia to establish the viability of the luxury market there. Next, we will discuss the theory and literature underlying the interactional impact of a variety of demographic variables on the desire for and willingness to spend valuable resources on luxury products and services.

\subsection{Tunisia as an Emerging Market for Luxury: The Economic Perspective}

Even before the start of the Arab Spring in 2010, Tunisia's economy was a healthy one. Inflation was contained, the country had sufficient reserves and the economy was growing at a healthy $5 \%$ annually. Further, after gaining independence in 1956, various modernization initiatives like banning polygamy, which created more autonomy and economic independence for women, had a significant impact on purchasing ability (Maddy-Weitzman, 2011). Further, an active and educated workforce (Sanchez, 2009) has fostered a robust demand for products and services. Although Tunisia has a lower middle income of about $\$ 3500$ per capita, the middle $60 \%$ of the population earns about half of all income, suggesting robust and well distributed spending power in the population (The World Bank, n.d.). Overall, from the standpoint of the economy, it is reasonable to view Tunisia as a country that represents an emerging market for luxury goods and services.

\subsection{Tunisia as an Emerging Market for Luxury: The Socio-Political Perspective}

Tunisia's geographic location attracts millions of tourists each year (Sanchez, 2009). Further, the Tunisian government has always seen value in good relations, economically and politically, with the developed countries of the West. Exchange of products, services and human capital with the western world has created investment and job opportunities (Martin, 2012). Overall, the political environment has allowed Tunisians to interact with and learn from other western countries. This is one factor in creating the desire for luxury products and services.

From the socio-political perspective, Tunisia's elected government opposed the institution of Sharia Islamic Law, the ban on alcohol and payment of interest on money. Such a stance further attracts foreign investors and visitors to Tunisia (Bishku, 2013). Although most of the Arab world has been much more open to economic and social development (Al-Momani, 2011), Tunisia, in particular, seems to be especially promising in these regards. In fact, strong testimony to the progressive nature of Tunisia is The World Economic Forum describing the Tunisian economy as 
the most competitive in Africa and in the Arab world (Sanchez, 2009). Coupled with the progressive political environment, the generally higher education levels of the Tunisian population, their incomes and exposure to the western way of life suggest a robust interest in luxury products and services. Given the recency of the Arab Spring and rapid liberalization across the Arab world, it is very timely to explore motivations of consumers for luxury products in Tunisia. It would be reasonable to expect that the results we find here will likely translate to other culturally similar emerging markets.

\subsection{Theoretical Background}

The desire for and purchase of luxury products in the developed world is well established. In fact, the valuation of the world luxury market quadrupled between 1990 and 2012 and continues to grow (Monkhouse et al., 2012). The two most common reasons for such desire are the generally better quality of luxury products and the social display value that they provide their users. In the context of social display, a long-standing theory of conspicuous consumption establishes that individual's purchase behaviors are, in part, determined by an innate need to mimic persons in social groups that they aspire to join or be associated with (Veblen, 1994). Hence, the need that individuals have for association with groups that are higher than them in social standing would be fulfilled partially by the conspicuous consumption of luxury products that separate social hierarchies, given that luxury products are expensive and often indicative of social position. Interestingly, this desire for luxury seems to be increasingly spreading to countries with limited resources (Souiden et al., 2011). Since such contagion of luxury product desire is spreading more than ever before, it is likely that increased awareness and enhanced information sharing have a significant role to play. Not surprisingly, as countries liberalize, the availability of the Internet allows populations to observe the glitter of luxury brands that are sought elsewhere. This trend has been observed in emerging economies like Brazil, India and China, where the growth rates in the luxury market range from $20 \%$ to $35 \%$. These extraordinary rates are attributed to both affluent customers and aspirant consumers with less wealth but an interest to seek social status (Souiden et al., 2011). With such trends, it is not surprising that luxury manufacturers have attempted to capture this mass market with the provision of products that are more affordable but carry the luxury brand (Souiden et al., 2011). Such "premium but attainable" luxury products (Soyoung \& Jongeun, 2011) that are mass marketed and meant for the middle classes are now a common feature of the luxury landscape.

One reason for such vigorous interest in luxury products is the cultural fabric of the non-western world. Most Asian nations score high on the cultural dimensions of power distance and collectivism (Hofstede, 2001). These dimensions provide the theory that partially explains the propensity in non-Western societies to desire luxury. High power distance societies, which most Asian and Middle Eastern countries are (Hofstede, 2001), tend to seek and accentuate power distances amongst people. A manifestation of this cultural leaning would be to use distinctive luxury products to magnify any status or power difference between people. In the same vein, highly collectivist societies, which typically are high in power distance as well, tend to use products that help them conform to norms that are imposed by societal groups of which they are a part of or aspire to be a part of.

Interestingly, although Tunisia is culturally very similar to the typical Middle Eastern society, its 
exposure to luxury is somewhat more recent. Hence, as a representation of an emerging market for luxury products, the attitudes and behaviors found in Tunisia are likely to inform many other societies that may find themselves in Tunisia's position in time to come. Academic inquiry into the attitudes and behaviors pertaining to luxury consumption is important from multiple perspectives. From the theoretical perspective, such studies help to understand the antecedents and consequences of such consumption and the interactions of these antecedent variables. For managers, such work provides deeper insights into how to position such products. For public policy makers and societies such work may reveal trends and desires that need to be managed. Specifically, it is of particular concern when exposure to luxury products creates a possibly unsustainable desire in consumers who are younger. Such consumers are particularly susceptible to peer pressure, celebrity behavior and media exposure.

A caveat is necessary, however. Although our theoretical grounding comes from the fundamental notion that consumers are likely to mimic the conspicuous consumption behaviors of social groups they aspire to, it is important to recognize that not all such behavior occurs in this "trickle down" (Trigg, 2001) manner, where consumers merely mimic aspirational social groups. Other viewpoints suggest a more nuanced approach, whereby conspicuous consumption may be desired due to factors beyond mere aspirations to mimic higher social groups. For instance, Bourdieu (1984), introduces the idea that the consumption of luxury may well be based on a variety of practical reasons as well, which may include an aspiration to acquire the cultural capital of a higher social group. For instance, consumers may eventually seek certain products and services to achieve a functional, rather than a social goal. As an example, owning a piano and learning to play it may be seen initially as a desirable behavior of a higher social group. However, consumers may eventually acquire sufficient cultural capital and view the piano and the ability to play as a selfindulgent pleasure and a tool to improve one's intellectual capacity. Thus, such reasons for luxury products may manifest as people learn and evolve. Bourdieu (1984) introduced the notion of a variety of other factors, including socio-demographic, that may influence the varying needs underlying the desire for luxury products. It is from this perspective, rather than the more rigid "trickle down" theory of conspicuous consumption, that we continue to further explore antecedents of luxury consumption. Earlier work tests and demonstrates that age, education and income have independent and significant impact on the desire for and consumption of luxury products (Gupta \& Zaghdoudi, 2016). In this research, we extend their work by exploring key interactions of these direct relationships. Thus, the specific purpose of this research is to extend current understanding of Tunisian luxury consumption motivations and behaviors by probing deeper into interactional relationships with the key independent variable of age and the interactions with other demographic variables on luxury desire and spending. Such an exploration should enable a richer and more nuanced understanding of luxury consumption.

Given that luxury consumption generally consumes significant resources, it is important to recognize the potential impacts of the coronavirus pandemic on the luxury market in 2020 and beyond. To the extent luxury consumption is likely to be costly and often substitutable by less expensive products, it is reasonable to speculate that the luxury market will be negatively impacted due to job losses, furloughs and a lack of mobility caused by the pandemic. Although this is indeed the case, preliminary research suggests that this downward trend may be temporary (Achille \& Zipser, 2020). It is likely that in the near term, the consideration sets of aspirational luxury products may change somewhat and the buying mechanisms may change to an online purchasing 
environment (Achille \& Zipser, 2020). The mechanisms of promotion and interpersonal influence may get altered as well. Since people are socially distant, online social media may take on a greater role in spreading the interpersonal influence in relation to luxury products (Achille \& Zipser, 2020; D'Arpizio et al., 2020). Overall, the limited research available that explores the impact of the coronavirus on luxury consumption suggests that the luxury market will decline temporarily and the manner of influence and the choice of luxury products may become somewhat altered, given that social display of products is altered to a more online format (D'Arpizio et al., 2020). Thus, we expect that, in the short term, luxury consumption may decline. Further, the mechanism of interpersonal influence, the specific sets of luxury products desired and the conspicuous display formats utilized may be dictated by conditions imposed by the pandemic on human interaction. In conclusion, we expect that, in the longer term, luxury consumption and desire will be restored to what it was prior to the coronavirus pandemic. Therefore, we believe that our theoretical findings will remain robust.

Hence, the purpose of this research is to extend current understanding of Tunisian luxury consumption motivations and behaviors from the age perspective. As discussed earlier, recent empirical research does demonstrate that younger consumers in Tunisia do seem to have a significantly stronger desire for and spend more of their income on luxury compared to older consumers (Gupta \& Zaghdoudi, 2016). As an extension to this previous work, this research studies key demographic moderator variables to enable a richer understanding by exploring the interaction between age and a variety of moderator variables.

\section{HYPOTHESES}

\subsection{Luxury Desire}

Generally, younger consumers are more exposed than older consumers to information sources that celebrate luxury products. Social media, traditional advertising and Internet access may contribute strongly to such exposure. Further, they are more likely than older consumers to conform to social groups that profess a desire for these luxury products. Empirical evidence that younger consumers have a stronger desire for luxury and spend more on luxury than older consumers already exists (Gupta \& Zaghdoudi, 2016). To extend that work, this research delves deeper into these relationships to study variables that may moderate the fundamental relationship between age and desire for luxury. Empirical research has shown that women, in the Western context, have a more positive attitude to luxury than men (Stokburger-Sauer \& Teichmann, 2013), perhaps due to a stronger susceptibility to peer influence. In the context of the emerging market in Tunisia, it is reasonable to expect that gender behaviors towards luxury products are likely to be similar. Thus, we expect that the relationship between age and luxury desire will be moderated by gender as follows:

H1a: The inverse relationship between age and desire for luxury products will be stronger for women compared to men.

To the extent a lack of income, in general, may heighten the aspirational drive to achieve luxury and the associated benefits of social acceptance, self-worth or prestige, it is likely that lower income consumers may be more willing to purchase luxury. That is, luxury products may serve as a mask to cover lower income or lower status in society. However, from the interactional perspective, the irrationality to desire luxury with a low income is more likely to be prevalent 
amongst younger consumers. In other words, older consumers may allow their sense of practicality to dominate the need for luxury products despite their higher income. Thus,

$\mathrm{H} 1 \mathrm{~b}$ : The inverse relationship between age and desire for luxury products will be stronger

for lower income compared to higher income consumers.

Further, another factor that is likely to interact with age would be the educational level of the consumer. All else being equal, education is likely to provide a counterbalance to the occasional irrational desire for the consumption of luxury. In other words, peer and social pressure, advertising enticements and the glitz of celebrities are temptations for luxury that may be tempered by the rationalization that education may provide. Hence, we expect,

H1c: The inverse relationship between age and desire for luxury products will be stronger for less educated compared to more educated consumers.

Finally, we expect that marital status will have a role to play in moderating the relationship between age and desire for luxury products. Essentially, single consumers, as compared to married couples, are more likely to be susceptible to external influences. To the extent that marriage may provide counterbalancing viewpoints towards luxury consumption decisions, it seems reasonable to expect that married couples' susceptibility to external influences may be less. Therefore, we expect the following relationship to hold true,

H1d: The inverse relationship between age and desire for luxury products will be stronger for single consumers compared to married consumers.

\subsection{Luxury Spending}

Next, we present hypotheses pertaining to the actual percentage of income spent on luxury. It is important to recognize that although the theoretical rationale for the following hypotheses follow closely from the theory presented in $\mathrm{H} 1 \mathrm{a}-\mathrm{H} 1 \mathrm{~d}$, testing these hypotheses represents an important extension to what we could learn from testing only H1a to H1d. It is possible that consumers may have the admiration for luxury products and desire them but not expend the resources to acquire them. Thus, in the following hypotheses, we explore the actual spending behavior of consumers on luxury products. It is important to note that the variable of interest is not the actual quantum of money, but the percentage of income spent on luxury. Clearly, at different levels of income, the actual manifestation of luxury spending may be different.

Consistent with the theory discussed earlier, we expect that younger consumers are more likely to act on their desires for luxury products by spending the required money to acquire that product but that this effect is likely to be accentuated for female consumers (Stokburger-Sauer \& Teichmann, 2013). Hence,

H2a: The inverse relationship between age and the percentage of income spent on luxury products will be stronger for women compared to men.

From the perspective of income, we expect that lower income consumers who perhaps have a heightened sense of desire for luxury products to mask their lower status or societal position may tend to spend more than individuals with more income on luxury products. That is, lower income consumers may feel they have more to gain with luxury consumption and less to lose with an already low level of income. Therefore, we expect that this willingness to spend more will interact with age in the following manner,

$\mathrm{H} 2 \mathrm{~b}$ : The inverse relationship between age and the percentage of income spent on luxury products will be stronger for lower income compared to higher income consumers. 
Further, as education rises, the ability to counter argue the perils of incurring excessive expense on luxury products is likely to rise as well. We expect this relationship to be stronger as a consumer grows in age. Thus,

H2c: The inverse relationship between age and the percentage of income spent on luxury products will be stronger for less educated compared to more educated consumers.

Lastly, it seems reasonable to expect that marriage will provide consumers with alternative viewpoints to those suggested by media, celebrities and peers. Thus, from the interactional perspective, we expect that the fundamental inverse relationship between age and income spent will be stronger for single consumers, compared to married consumers. Formally stated,

$\mathrm{H} 2 \mathrm{~d}$ : The inverse relationship between age and the percentage of income spent on luxury products will be stronger for single compared to married consumers.

\section{METHODOLOGY}

The sample was developed from Tunisian Facebook users. The seed sample was developed from Facebook friends and acquaintances of the second author. Essentially, the method was to request these friends and acquaintances to complete the survey. Next, they were requested to ask at least 5 of their Facebook friends to complete this survey, who were not part of the original group. The survey was conducted in both the English and French languages. The translation from English to French was done by a certified translator in Tunisia. It is important to note that no pressure was applied, and no incentives were given to complete the survey. The motivations invoked were a willingness to help friends and acquaintances and an interest in participating in academic research pertaining to luxury consumption in Tunisia. From the perspective of a sampling frame, it is important to note that given the demographic profile of the second author, we expected that many respondents in our seed sample of her friends on Facebook were going to include a younger demographic profile, who had relatively less income and education. However, in the second phase of the cascading sample, where the seed group forwarded the survey to a minimum of 5 of their Facebook friends, we expected their family members who were friends with them on Facebook would be older and have higher education levels and incomes. Hence, we were able to achieve a reasonably well distributed sample of respondents across genders, ages, incomes and educational levels. Given that each respondent was responding to a friend on Facebook, their involvement levels in the study were sufficiently high. As a result of that involvement, we received 196 records that were included in our analyses.

\section{RESULTS AND DISCUSSION}

\subsection{Sample and Questionnaire}

The final sample which we used to test the hypotheses was composed of 196 respondents. The demographic profile of the sample is presented in Table 1.

We provide a measure of validity of the sample by comparing it with Tunisian population statistics obtained during the time the sample was collected. The Tunisian population age distribution is roughly $38 \%$ below 24 years of age, about $52 \%$ in the $25-64$ age and roughly $8 \%$ over 65 years of age (CIA, n.d.). Our sample age statistics of $36.8 \%$ below 25 years of age, $48.9 \%$ between $26-55$ 
and $2.7 \%$ over 55 seem to be a reasonable representation of the population. Second, Tunisian literacy rate is about $82 \%$ (CIA, n.d.). Our sample has more than $60 \%$ of the respondents with a minimum of a bachelor's degree. This could be perhaps due to using a Facebook sample, which is likely to have more literate users anyway.

Table 1: Demographic Characteristics of the Respondents

\begin{tabular}{|c|c|c|c|c|}
\hline $\begin{array}{l}\text { Sample } \\
\text { Size }\end{array}$ & Gender & Age & $\begin{array}{l}\text { Annual Income in US } \\
\text { Dollars }\end{array}$ & Education \\
\hline 196 & $\begin{array}{l}\text { Males }(74,33.2 \%)^{*} \\
\text { Females }(123,55.2 \%)\end{array}$ & $\begin{array}{l}18-25(82,36.8 \%)^{*} \\
26-35(74,33.2 \%) \\
36-45(20,9.0 \%) \\
46-55(15,6.7 \%) \\
>55(6,2.7 \%)\end{array}$ & $\begin{array}{l}\$ 0-2275(61,27.4 \%)^{*} \\
\$ 2275-4550(37,16.6 \%) \\
\$ 4550-11375(68,30.5 \%) \\
>\$ 11375(31,13.9 \%)\end{array}$ & $\begin{array}{l}\text { High School }(23,10.3 \%)^{*} \\
\text { Bachelors }(47,21.1 \%) \\
\text { Masters }(76,34.1 \%) \\
\text { Doctorate }(37,16.6 \%)\end{array}$ \\
\hline
\end{tabular}

The questionnaire first collected demographic information, including income level, age, marital status and educational level. The income levels used were typical of the distribution of incomes in Tunisia during the time the data was collected. Next, the questionnaire asked respondents to report whether they already owned any luxury products (Yes/No). To ensure a reasonably consistent definition of luxury, respondents were provided with examples of brands typically deemed luxurious in Tunisia, like Louis Vuitton, Burberry, Dior and Chanel. Those that answered "No" were asked about their willingness to purchase luxury in the future. (details of the variable and measures used are provided in Table 2).

\subsection{Desire for Luxury}

This section explores the results of the hypotheses testing. A description of the variables and measures used for each hypothesis, the methodology used and the sample sizes is presented in Table 2. A summary of the hypotheses testing is provided in Table 3 . To test H1, the sample was first adjusted to consumers who did not own a luxury product, which allowed us to study their willingness to purchase luxury in the future. Since the resulting sample sizes used to test the hypotheses are small due to this restriction, we used p-values of less than or equal to $10 \%$ to determine statistical significance. Further, since all the variables used were categorical in H1a to H1d, we used cross tabulations in SPSS 25 and tested the relationships using the Pearson chisquare statistic. It is important to note that since older consumers reported already having luxury products, our hypothesis testing restricted to two age groups - the 18-25 age group and the 25-35 age group $(n=47)$. Hypothesis la studies the interactions between age and gender on the willingness to purchase luxury products (assuming one did not own them already). Consistent with H1a, which tests the theory that the inverse relationship between age and desire for luxury will be moderated by gender such that the effect will be more pronounced for women compared to men, we find that for women, the inverse relationship between age and luxury desire is significant $\left(\chi^{2}\right.$ $=2.65, \mathrm{p}<0.10)$, whereas for men the relationship is not significant. That is, younger women are significantly more willing to purchase luxury products compared to older women, but this relationship does not hold true for men $\left(\chi^{2}=2.10, \mathrm{p}<0.15\right)$. 
Table 2: Variables, Measurements and Analyses Utilized in Examining the Inverse Relationship Between Age and Luxury Consumption in Tunisia Luxury Market

H1: The sample was restricted to respondents who reported "No" to the question, "Do you own at least one luxury brand?" (Yes/No). The sample size was small $(\mathrm{N}=47)$. Since all the measures used were categorical, the hypotheses were tested using cross-tabulations in SPSS 25 using the Pearson Chi-Square Statistical Test. Summary test results are reported in Table 3 (details in text).

\begin{tabular}{|l|l|l|}
\hline Hypothesis & Variables and Measures & Notes \\
\hline H1a & $\begin{array}{l}\text { IV*: Two age categories (18-25 and 25-35). } \\
\text { DV*: Are you willing to buy a luxury product? (Yes / No) } \\
\text { MV*: Gender (Male /Female) }\end{array}$ & $\begin{array}{l}\text { Although age was measured on five categories (18-25, 26-35, 36-45, 46-55, 56-65, >65) the } \\
\text { sample of consumers who did not own a luxury brand was composed of the two lowest age } \\
\text { groups. }\end{array}$ \\
\hline H1b & $\begin{array}{l}\text { IV*: Two age categories (18-25 and 25-35). } \\
\text { DV*: Are you willing to buy a luxury product? (Yes / No) } \\
\text { MV*: Income Level (Low/High). }\end{array}$ & $\begin{array}{l}\text { Although income was measured in four categories (0-5000 TND, 5000-10000 TND, 10000- } \\
\text { 30000 TND and }>30000 \text { TND), the sample size was too small to test all categories. Hence, } \\
\text { we collapsed the sample to two categories of income (below 10000 TND and above 10000 } \\
\text { TND). }\end{array}$ \\
\hline H1c & $\begin{array}{l}\text { IV*: Two age categories (18-25 and 25-35). } \\
\text { DV*: Are you willing to buy a luxury product? (Yes / No) } \\
\text { MV*: Education Level (Low/High). }\end{array}$ & $\begin{array}{l}\text { Although respondents reported one of four levels of their Highest Level of Education } \\
\text { collapsed (High School Diploma, Bachelor's Degree, Master's Degree or Ph.D. degree), we } \\
\text { of Lower versus Higher education due to the small sample size. }\end{array}$ \\
\hline H1d & $\begin{array}{l}\text { IV*: Two age categories (18-25 and 25-35). } \\
\text { DV*: Are you willing to buy a luxury product? (Yes / No) } \\
\text { MV*: Marital Status (Single/Married). }\end{array}$ & Marital Status was measured with a self-report of Are You: Single or Married. \\
\hline
\end{tabular}

H2: The sample was restricted to respondents who reported "Yes" to the question, "Do you own at least one luxury brand?" (Yes/No). The sample size was $(\mathrm{N}=140)$. Since all the measures used were categorical, the hypotheses were tested using cross-tabulations in SPSS 25 using the Pearson Chi-Square Statistical Test. Summary test results are reported in Table 3 (details in text).

\begin{tabular}{|l|l|l|}
\hline H2a & $\begin{array}{l}\text { IV: Two age categories (Below 35 and Above 35) } \\
\text { DV: Two categories of expenditure on luxury (Low/High) } \\
\text { MV: Gender (Male/Female) }\end{array}$ & $\begin{array}{l}\text { Although age was measured on five categories (18-25, 26-35, 36-45, 46-55, 56-65, }>65), \text { we } \\
\text { collapsed respondents into 2 groups }- \text { Below 35 years and Above 35 years. Respondents self- } \\
\text { reported on “What percentage of your annual income do you spend on luxury products?". The } \\
\text { choices were }<5 \%, 5 \%-20 \%, 20 \%-40 \% \text { and }>40 \% \text {. We collapsed the data into two groups of } \\
\text { Low Annual Luxury Expense (below 20\%) and High Annual Luxury Expense (above 20\%). }\end{array}$ \\
\hline H2b & $\begin{array}{l}\text { IV: Two age categories (Below 35 and Above 35) } \\
\text { DV: Two categories of expenditure on luxury (Low/High) } \\
\text { MV: Income Level (Low/High). }\end{array}$ & $\begin{array}{l}\text { Although income was measured in four categories (0-5000 TND, 5000-10000 TND, 10000- } \\
30000 \text { TND and }>30000 \text { TND), we collapsed the sample to two categories of income (below } \\
10000 \text { TND and above 10000 TND). }\end{array}$ \\
\hline $\begin{array}{l}\text { IV: Two age categories (Below 35 and Above 35) } \\
\text { DV: Two categories of expenditure on luxury (Low/High) } \\
\text { MV: Education Level (Low/High) }\end{array}$ & $\begin{array}{l}\text { Although respondents reported one of four levels of their Highest Level of Education } \\
\text { Completed (High School Diploma, Bachelor's Degree, Master's Degree or Ph.D. degree), we } \\
\text { collapsed the data into Bachelor's and below and Master's and above, created two categories } \\
\text { of Lower versus Higher education. }\end{array}$ \\
\hline H2d & $\begin{array}{l}\text { IV: Two age categories (Below 35 and Above 35) } \\
\text { DV: Two categories of expenditure on luxury (Low/High) } \\
\text { MV: Marital Status (Single/Married). }\end{array}$ & Marital Status was measured with a self-report of Are You: Single or Married. \\
\hline
\end{tabular}

*IV - Independent Variable; DV - Dependent Variable; MV - Moderator Variable 
Next, H1b hypothesized that the inverse relationship between age and luxury desire would be stronger for lower income consumers, attributed to the fundamental theory that when income is lower, the interest in luxury is stronger since the desire to conform or mask one's lack of status or success will be higher as well. For ease of exposition, the income categories were collapsed into two groups - a lower income and an upper income group. In support of H1b, we find that amongst lower income consumers, younger consumers are significantly more willing to purchase luxury products compared to older consumers $\left(\chi^{2}=4.20, \mathrm{p}<0.04\right)$, but this relationship is not statistically significant for the higher income group $\left(\chi^{2}=0.28, \mathrm{p}<0.60\right)$. Thus, H1b is supported.

The next hypothesis, H1c, purports that the inverse relationship between age and desire for luxury will be stronger for less educated consumers compared to more educated consumers. The results show that for less educated consumers, lower age does not lead to a stronger desire for luxury $\left(\chi^{2}\right.$ $=0.37, \mathrm{p}<0.51$ ). However, for less educated consumers, $91 \%$ of the younger age group and $80 \%$ of the older age group were willing to purchase luxury, which is in line with the expectations of the hypothesis. For the higher educated, the relationship was significant $\left(\chi^{2}=2.77, p<0.096\right)$. That is, at higher educational levels, the younger consumers had a stronger willingness to purchase luxury. Thus, H1c is not supported.

Hypothesis 1d proposes that the inverse relationship between age and luxury desire will be stronger for singles. The theory is that married consumers may be able to counter argue the desire for luxury. The results support this hypothesis. For singles, younger consumers have significantly stronger desires to buy luxury if they do not already own luxury $\left(\chi^{2}=2.56, p<0.10\right)$. For married consumers, the inverse relationship does not hold true (the cell sizes were identical, hence no statistics were generated). Thus, H1d is supported.

\subsection{Luxury Spending}

Next, we test Hypothesis 2, which explores the self-reported annual percentage of income spent on luxury products as the key dependent variable. A description of the variables and measures used for each hypothesis, the methodology used and the sample size is presented in Table 2. A summary of the interactional hypotheses testing is provided in Table 3. For the following analyses, we restrict the sample to those consumers who already own a luxury product $(n=140)$. Further, for brevity, we divided the sample into two age categories - below and above 35 years of age. For the expenditure category, we used two categories as well - below and above $20 \%$ of self-reported annual percentage of income spent on luxury products. Further, since all the variables used were categorical in $\mathrm{H} 2 \mathrm{a}$ to $\mathrm{H} 2 \mathrm{~d}$, we used cross tabulations in SPSS 25 and tested the relationships using the Pearson chi-square statistic.

$\mathrm{H} 2 \mathrm{a}$ purports that the inverse relationship between age and percentage of income spent on luxury products will be stronger for women compared to men. This hypothesis is supported. For men, the relationship between age and luxury expense is not supported $\left(\chi^{2}=0.74, p<0.39\right)$, whereas for women, the relationship clearly shows that younger women spend significantly more (greater than $20 \%$ of annual income) than older women on luxury products $\left(\chi^{2}=5.96, \mathrm{p}<0.02\right)$.

The expectation in $\mathrm{H} 2 \mathrm{~b}$ is that the inverse relationship between age and luxury spending would be such that the relationship would be stronger for lower income consumers compared to higher 
Table 3: Interactional Hypotheses Testing Results for Examining the Inverse Relationship Between Age and Luxury Consumption in Tunisia Luxury Market

\begin{tabular}{|c|c|c|c|}
\hline Hypothesis 1 & Basic Relationship & Measures & Support \\
\hline $\begin{array}{l}\text { Moderated by... } \\
\text { Basic Relationship... }\end{array}$ & $\begin{array}{l}\text { Lower the age, stronger the desire } \\
\text { for luxury products... }\end{array}$ & $\begin{array}{l}\text { IV: Two age categories (Between } 18-25 \text { and } 25-35 \text { ) } \\
\text { DV: Are you willing to buy a luxury product? (Sample } \\
\text { restricted to respondents who did not own a luxury } \\
\text { product prior). }\end{array}$ & Yes, $\mathrm{p}<0.03$ \\
\hline H1(a) & $\begin{array}{l}\text { Above relationship stronger for } \\
\text { females compared to males }\end{array}$ & Moderator variable: Gender in two categories & Yes; $\mathrm{p}<0.10$ \\
\hline H1(b) & $\begin{array}{l}\text { Above relationship stronger for lower } \\
\text { compared to higher income consumers }\end{array}$ & $\begin{array}{l}\text { Moderator variable: Self-reported income categories } \\
\text { collapsed to two categories. Lower and Higher } \\
\text { incomes. }\end{array}$ & Yes; $\mathrm{p}<0.04$ \\
\hline $\mathrm{H} 1(\mathrm{c})$ & $\begin{array}{l}\text { Above relationship stronger for less } \\
\text { compared to more educated consumers }\end{array}$ & $\begin{array}{l}\text { Moderator variable: Two categories of education. } \\
\text { Bachelors and below and Masters and above. }\end{array}$ & No \\
\hline $\mathrm{H} 1(\mathrm{~d})$ & $\begin{array}{l}\text { Above relationship stronger for single } \\
\text { compared to married consumers }\end{array}$ & $\begin{array}{l}\text { Moderator variable: Two categories of relationships } \\
\text { status. Single and Married. }\end{array}$ & Yes; $p<0.10$ \\
\hline \multicolumn{4}{|l|}{ Hypothesis 2} \\
\hline $\begin{array}{l}\text { Moderated by... } \\
\text { Basic Relationship... }\end{array}$ & $\begin{array}{l}\text { Lower the age, larger the expenses } \\
\text { on luxury products... }\end{array}$ & $\begin{array}{l}\text { IV: Two age categories (Below } 35 \text { and Above } 35 \text { ) } \\
\text { DV: Two categories of expenditure on luxury. Below } \\
20 \% \text { of annual income and above } 20 \% \text { of annual } \\
\text { income (self-reported). }\end{array}$ & Yes, $\mathrm{p}<0.01$ \\
\hline $\mathrm{H} 2(\mathrm{a})$ & $\begin{array}{l}\text { Above relationship stronger for } \\
\text { females compared to males }\end{array}$ & Moderator variable: Gender in two categories & Yes, $\mathrm{p}<0.02$ \\
\hline $\mathrm{H} 2(\mathrm{~b})$ & $\begin{array}{l}\text { Above relationship stronger for lower } \\
\text { compared to higher income consumers }\end{array}$ & $\begin{array}{l}\text { Moderator variable: Self-reported income categories } \\
\text { collapsed to two categories. Lower and Higher } \\
\text { incomes. }\end{array}$ & $\begin{array}{l}\text { No; partial } \\
\text { support only }\end{array}$ \\
\hline $\mathrm{H} 2(\mathrm{c})$ & $\begin{array}{l}\text { Above relationship stronger for less } \\
\text { compared to more educated consumers }\end{array}$ & $\begin{array}{l}\text { Moderator variable: Two categories of education. } \\
\text { Bachelors and below and Masters and above. }\end{array}$ & Yes, $\mathrm{p}<0.01$ \\
\hline $\mathrm{H} 2(\mathrm{~d})$ & $\begin{array}{l}\text { Above relationship stronger for single } \\
\text { compared to married consumers }\end{array}$ & $\begin{array}{l}\text { Moderator variable: Two categories of relationships } \\
\text { status. Single and Married. }\end{array}$ & $\begin{array}{l}\text { No; partial } \\
\text { support only }\end{array}$ \\
\hline
\end{tabular}


income consumers. The fundamental theory here is that at a lower earned income level, consumers would have a heightened need for luxury display and social acceptance. For ease of exposition, respondents were placed in two categories, low and high income, based on the self-report of their income levels. Although the results show that $31 \%$ of the younger consumers in the lower income group spent a larger proportion (greater than $20 \%$ of their income) on luxury compared to none of the older consumers in the lower income group $\left(\chi^{2}=2.19, \mathrm{p}<0.14\right)$. It is important to note that although the difference is not statistically significant, due to a low cell count in two of the cells, the directional support is compelling. On the other hand, only $18 \%$ of the younger consumers of the higher income consumers spent greater than $20 \%$ of their income, compared to $4.1 \%$ of older consumers in the higher income group $\left(\chi^{2}=2.60, \mathrm{p}<0.11\right)$. This result is not statistically significant. Hence, we are only able to partially support $\mathrm{H} 2 \mathrm{~b}$.

Next, H2c hypothesizes that the inverse relationship between age and luxury spending would be more robust for less educated consumers. This expectation stems from the theory that more education would lead to more justification of such expenses and would lead to more counter argumentation in the consumers' mind. For ease of exposition, we created two categories of educational levels - one for high school and bachelor level education and one for master level degrees and above. Consistent with the expectations of $\mathrm{H} 2 \mathrm{c}$, we find that for lower levels of education, the younger consumers spent significantly more on luxury compared to older consumers $\left(\chi^{2}=5.97, \mathrm{p}<0.01\right)$. However, the inverse relationship between age and luxury expenditure does not hold for higher educated consumers $\left(\chi^{2}=1.67, \mathrm{p}<0.20\right)$.

Finally, H2d theorizes that the inverse relationship between age and luxury expense will be stronger for single consumers compared to married ones, given the ability to rationalize and be less susceptible to social and media influence in the presence of a spouse. Similar to the cell size limitations found in $\mathrm{H} 2 \mathrm{~b}$, we find that the results are not statistically significant for single consumers due to two cells having low cell counts $\left(\chi^{2}=0.74, p<0.34\right)$. However, for single consumers, $27 \%$ of the younger consumers spent more ( $20 \%$ of income) on luxury, whereas none of the older singles did so. For married consumers, $17 \%$ of the younger consumers spent more than $20 \%$ on luxury products, whereas $4 \%$ of the older ones did so $\left(\chi^{2}=2.05, p<0.15\right)$. Thus, due to lower cell sizes, we can only partial support $\mathrm{H} 2 \mathrm{~d}$.

\section{CONCLUSIONS}

\subsection{Insights}

Past research has presented empirical evidence that age, education and income do have direct and independent impacts on the desire for luxury products and the willingness to spend money for these products. This research delved deeper by hypothesizing and testing interactional relationships between the antecedent variable of age with gender, income, education and marital status on the desire for and spending on luxury products. These insights are important for several reasons.

First, from the theoretical perspective, the results provide important boundary conditions to earlier results. For instance, we show that the fundamental inverse relationship between age and the desire for luxury is significant for younger women but not for men. Similarly, we are able to demonstrate 
that this inverse relationship is stronger for lower income consumers and not for higher income consumers and is stronger for single consumers as opposed to married ones. Further, this work largely supports the same interactions between gender, income, education and marital status and the inverse relationship between age and actual expenditure on luxury products. That is, we are able to show that this relationship is stronger for younger women and less educated consumers. However, we only have partial support for the theory that this relationship is stronger for lower income consumers and single (as opposed to married) consumers.

Second, the managerial insights from the interactional relationships established in this research are particularly useful. The knowledge that younger women, less educated and lower income consumers are particularly susceptible to luxury product consumption suggests more nuanced promotions to reach such consumers in forums that they may frequent.

Lastly, these moderated relationships allow public policy makers to better direct their messages to protect public welfare. Clearly, it would be of interest to public policy makers to ensure that younger consumers, particularly younger women, less educated and less wealthy sections of the population are be better informed on how to protect their resources. Luxury, per se, is not bad. Excessive desire and consumption of luxury may be. Public policy programs to restrict excessive and false promotions by sellers and to provide necessary education may be useful policy endeavors to ensure a healthy allocation of individual resources to luxury products, particularly amongst these more vulnerable groups in society.

\subsection{Limitations}

Although this study makes theoretical contributions by empirically testing interactional hypotheses and provides managers and public policy makers some valuable insights, we acknowledge some limitations. First, by virtue of having collected the data in one country, Tunisia, the generalizability of the results is somewhat limited. Although there may be significant similarities across countries that have similar cultures, generalizability remains limited. Second, the sample was conducted from Facebook users and is thus restricted to persons with the means, knowledge and resources to be engaged on such a platform. From the speculative perspective, such a sample is restrictive and may not fully represent a cross section of the Tunisian population. Third, the sample size is relatively small. To test certain hypotheses related to desire for luxury, we had to restrict the sample to individuals who did not already have luxury products, which made our sample very limited.

\subsection{Future Directions}

As a guide to further work, it is important to corroborate these results with larger samples within the Tunisian population and to conduct similar data collection in other countries as well to verify the robustness of the results. It would also be useful to test these hypotheses in a variety of different cultures. Lastly, with larger samples, it will be possible to extend this work by exploring other moderator variables and establish further boundary conditions to develop a fuller picture to understand the desire for luxury products. 


\section{REFERENCES}

Achille, A., \& Zipser, D. (2020, April). A perspective for the luxury-goods industry during-and after-coronavirus. McKinsey. https://www.mckinsey.com/industries/retail/our-insights/aperspective-for-the-luxury-goods-industry-during-and-after-coronavirus.

Al-Momani, M. (2011). The e Arab "youth quake": Implications on democratization and stability. Middle East Law and Governance, 3(1-2), 159-170. https://doi.org/10.1163/187633711x591521

Bishku, M. B. (2013). Is it an Arab Spring or business as usual? Recent changes in the Arab World in historical context. Journal of Third World Studies, 30(1), 55-77.

Bourdieu, P. (1984). Distinction: A Social Critique of the Judgment of Taste. Cambridge, MA: Harvard University Press.

CIA. (n.d.). The World Factbook. https://www.cia.gov/library/publications/the-worldfactbook/geos/ts.html

D'Arpizio, C., Levato, F., Fenili, S., Colacchio, F., \& Prete, F. (2020, March 26). Luxury after Covid-19: Changed for (the) Good? Bain. https://www.bain.com/insights/luxury-aftercoronavirus/.

Dadush, U., \& Dunne, M. (2011). American and European responses to the Arab Spring: What's the big idea? The Washington Quarterly, 34(4), 131-145. https://doi.org/10.1080/0163660x.2011.610728

Dziri, H. (2013). Assessing the entrepreneurial ecosystem in Tunisia. (Unpublished dissertation). MIT Sloan School of Management, Boston.

Gupta, P., \& Zaghdoudi, M. (2016). Motivations for Luxury Consumption: Insights from Tunisia's Emerging Market. Journal for the Advancement of Developing Economies, 5(1), 67-83. https://doi.org/10.13014/k2sq8xmq

Hofstede, G. (2001). Culture's consequences: comparing values, behaviors, institutions, and organizations across nations. SAGE Publications.

Le Monkhouse, L., Barnes B. R., \& Stephan, U. (2012). The influence of face and group orientation on the perception of luxury goods: A four market study of East Asian consumers. International Marketing Review, 29(6), 647-672. https://doi.org/10.1108/02651331211277982

Maddy-Weitzman, B. (2011). Middle Eastern Upheavals Tunisia's morning after. Middle East Quarterly, 18(3), 11-17. https:/www.meforum.org/middle-east-quarterly/pdfs/2977.pdf

Martin, J. (2012). It's not just the Arab Spring, it's the economy (stupid). Kennedy School Review, 12, 10-11.

Sanchez, A. (2009). Tunisia: trading, freedom for stability may not last - An international security perspective. Defence Studies, 9(1), 85-92. https://doi.org/10.1080/14702430802666660

Souiden, N., M'Saad, B., \& Pons, F. (2011). A cross-cultural analysis of consumers' conspicuous consumption of branded fashion accessories. Journal of International Consumer Marketing, 23(5), 329-343. https://doi.org/10.1080/08961530.2011.602951

Soyoung, O., \& Jongeun, K. (2011). Analysis of the marketing strategy of a luxury brand and its success in selected Asian countries. The International Journal of Interdisciplinary Social Sciences, 6(1), 239-257. https://doi.org/10.18848/1833-1882/CGP/v06i01/52004

Stokburger-Sauer, N., \& Teichmann, K. (2013). Is luxury a female thing? The role of gender in luxury brand consumption. Journal of Business Research, 66(7), 889-896. https://doi.org/10.1016/j.jbusres.2011.12.007 
Trigg, A. (2001). Veblen, Bourdieu, and conspicuous consumption. Journal of Economic Issues, 35(1), 99-115. https://doi.org/10.1080/00213624.2001.11506342

Veblen, T. (1994). The Theory of the Leisure Class. In The Collected Works of Thorstein Veblen, Vol. 1. 1899. Reprint, London: Routledge, 1994, 1-4040.

World Bank, (n.d.). http://data.worldbank.org/indicator/NY.GNP.PCAP.CD?locations 